\title{
PRZEDMOWA DO WYDANIA POLSKIEGO
}

Z niemałą satysfakcją przyjąlem propozycję dokonania przekładu książki W. Lampetera - „Zwalczanie chwastów w produkcji nasiennej”. Napisanie tej książki zostało podyktowane troską o podniesienie kultury rolnej $\mathrm{w}$ zakresie prowadzenia walki $\mathrm{z}$ chwastami $\mathrm{w}$ tak ważnej dla rolnictwa dziedzinie, jaką jest produkcja nasienna.

Prof. dr habil. Wilhelm Lampeter, dyrektor Instytutu Użytków Zielonych i Uprawy Pastewnych Roślin Polowych Uniwersytetu im. Karola Marksa w Lipsku, jest wybitnym znawcą biologii roślin pastewnych oraz eksperymentatorem $\mathrm{w}$ zakresie prowadzenia plantacji nasiennych różnych roślin pastewnych. Jego dążenie do uzyskania największych plonów nasion skłoniło Go do napisania tej książki, opartej na wieloletnich doświadczeniach własnych, prowadzonych w Instytucie Użytków Zielonych i Badań Torfowisk w Paulinenaue. Książka ta zapoznaje czytelnika $z$ istniejącą bogatą literaturą światową $\mathrm{w}$ tym zakresie oraz uwzględnia nie tylko tradycyjne metody walki z chwastami, ale obszernie omawia także nowsze osiągnięcia $\mathrm{w}$ zakresie rozsądnego stosowania chemicznych środków do zwalczania chwastów i roślin obcych na plantacjach nasiennych, nie pomijając także samej techniki młocki i czyszczenia nasion. Zawiera ona również nadzwyczaj trafne zestawienia cech rozpoznawczych i porównawczych roślin obcych i chwastów występujących na plantacjach nasiennych oraz starannie wykonane rysunki czarno-białe, jak też tablice barwne. To metodyczne i graficzne opracowanie książki podnosi dodatkowo jej walory dydaktyczne jako podręcznika i przewodnika dla szerokiej rzeszy agronomów i instruktorów nasiennictwa oraz kierowników gospodarstw nasiennych, pracujących bezpośrednio w produkcji nasiennej, a także całej służby doradczej w zakresie ochrony roślin. Może ona również stanowić cenną lekturę dla studentów wydziałów rolniczych oraz pomoc dla łąkarzy pracujących $\mathrm{w}$ terenie.

W dobie walki o wysoką jakość produkcji nasiennej ukazanie się tej książki w przekładzie polskim należy uznać za rzecz godną najwyższego uznania, a czytelnikom życzyć najszerszego wykorzystania jej treści.

Warszawa, styczeń 1966

doc. $d r$ Roman Moraczewski 
